\section{Autoradiographic Characterization of Beta Adrenergic Receptors in Coronary Blood Vessels and Myocytes in Normal and Ischemic Myocardium of the Canine Heart}

Kathryn H. Muntz, Edwin G. Olson, Gene R. Lariviere, Sandra D'Souza, Amal Mukherjee, James T. Willerson, and L. Maximilian Buja

Departments of Pathology and Internal Medicine, Cardiovascular Division, The University of Texas Health Science Center at Dallas, Texas 75235

myocytes. However, at $10^{-6} \mathrm{M}$ metoprolol, the percent reduction in specific DHA binding was greater for myocytes $(50 \%)$ than for arterioles $(0 \%)$, and at $10^{-7} \mathrm{M}$ metoprolol, the percent reduction in specific DHA binding was $17 \%$ for myocytes with no reduction over arterioles. After $1 \mathrm{~h}$ of LAD occlusion, a selective increase (18\%) in BAR density occurred over cardiac myocytes, but not over blood vessels in the ischemic myocardium. Thus, (a) specific BAR binding was five times greater in arterioles than in small arteries and myocardium and 34 times greater than in the proximal LAD; $(b)$ BAR of myocytes were more sensitive than those of arterioles to displacement by the beta one selective antagonist, metoprolol; and $(c)$ a selective increase in BAR occurs in cardiac myocytes but not in blood vessels after $1 \mathrm{~h}$ of ischemia in this experimental model.

\section{Introduction}

Catecholamines exert their physiological and pathophysiological effects by binding to specific catecholamine receptors. Physiological and radioligand binding studies have indicated that the heart has populations of beta one and beta two receptors $(1,2)$, and alpha one receptors (3). With regard to the localization of these receptors, studies as early as 1948 suggested that changes in myocardial contractility appear to be mediated primarily by the beta receptor, whereas changes in coronary blood vessels can involve alpha and beta receptors (4).

Physiological and radioligand binding studies have advanced the understanding of the beta adrenergic system in various pathophysiological states. These studies have documented changes in myocardial beta adrenergic receptor number with chronic beta adrenergic blockade, thyroid disorders, congestive heart failure, and acute ischemia $(5,6)$. Furthermore, the changes in receptor number have been correlated with changes in tissue responsiveness to catecholamines $(5,6)$. 


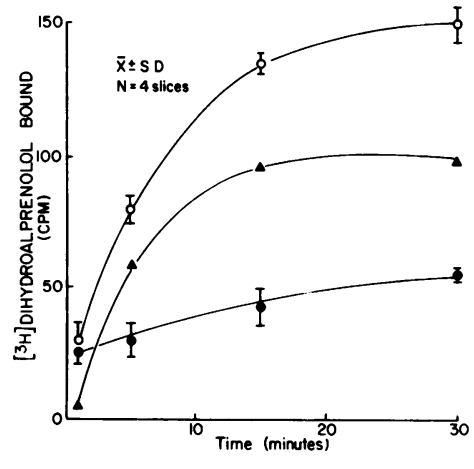

Figure 1. Total (0), specific $(\triangle)$, and nonspecific (•) binding of $2 \mathrm{nM}$ $\left.(-){ }^{3} \mathrm{H}\right] \mathrm{DHA}$ as a function of incubation time. Specific binding reached equilibrium at $\sim 15 \mathrm{~min}$. Nonspecific binding was determined by incubation of sections in $\left[{ }^{3} \mathrm{H}\right] \mathrm{DHA}$ in the presence of $10^{-5} \mathrm{M}( \pm)$ propranolol. Each point is derived from four tissue slices.

The standard radioligand binding assays are performed on tissue homogenates which are prepared from relatively large amounts of tissue and contain membranes from several cell types. These limitations have stimulated the search for autoradiographic and histochemical techniques to localize the betaadrenergic receptor (7-9). Recently, the autoradiographic localization of tritiated isoproterenol was reported in rat heart (10). However, no attempt was made to prevent diffusion of the ligand during histological processing, and because the ligand was injected, no correlation with biochemical data could be obtained. We used light microscopic autoradiography with levo- tritiated dihydroalprenolol (DHA), ${ }^{1}(-)\left[{ }^{3} \mathrm{H}\right] \mathrm{DHA}$, and a highly specific beta adrenergic antagonist (5) to study the distribution of beta adrenergic receptors over cardiac myocytes and blood vessels in the canine heart, using a technique that minimizes diffusion of the ligand and can be validated biochemically (7, 8 ). We also wanted to determine whether pharmacological and pathological interventions would produce selective alterations in beta receptors over various tissue components of the heart which could be detected by this method. We chose the beta one selective antagonist metoprolol as a pharmacological intervention and $1 \mathrm{~h}$ of myocardial ischemia as a pathological intervention. These studies were based on the hypotheses that $(a)$ the density of beta adrenergic receptors may differ in various components of the heart and $(b)$ beta adrenergic receptors in certain components of the heart may exhibit a selective response to pharmacological and pathological stimuli.

\section{Methods}

Tissue preparation. Mongrel dogs were anesthetized with sodium pentobarbital and placed on a respirator. The chest was opened and the

1. Abbreviations used in this paper: BAR, beta adrenergic receptor; CMC, cardiac muscle cell; DHA, dihydroalprenolol; $K_{\mathrm{D}}$, dissociation constant; LAD, left anterior descending coronary artery; MA, myocardial artery.

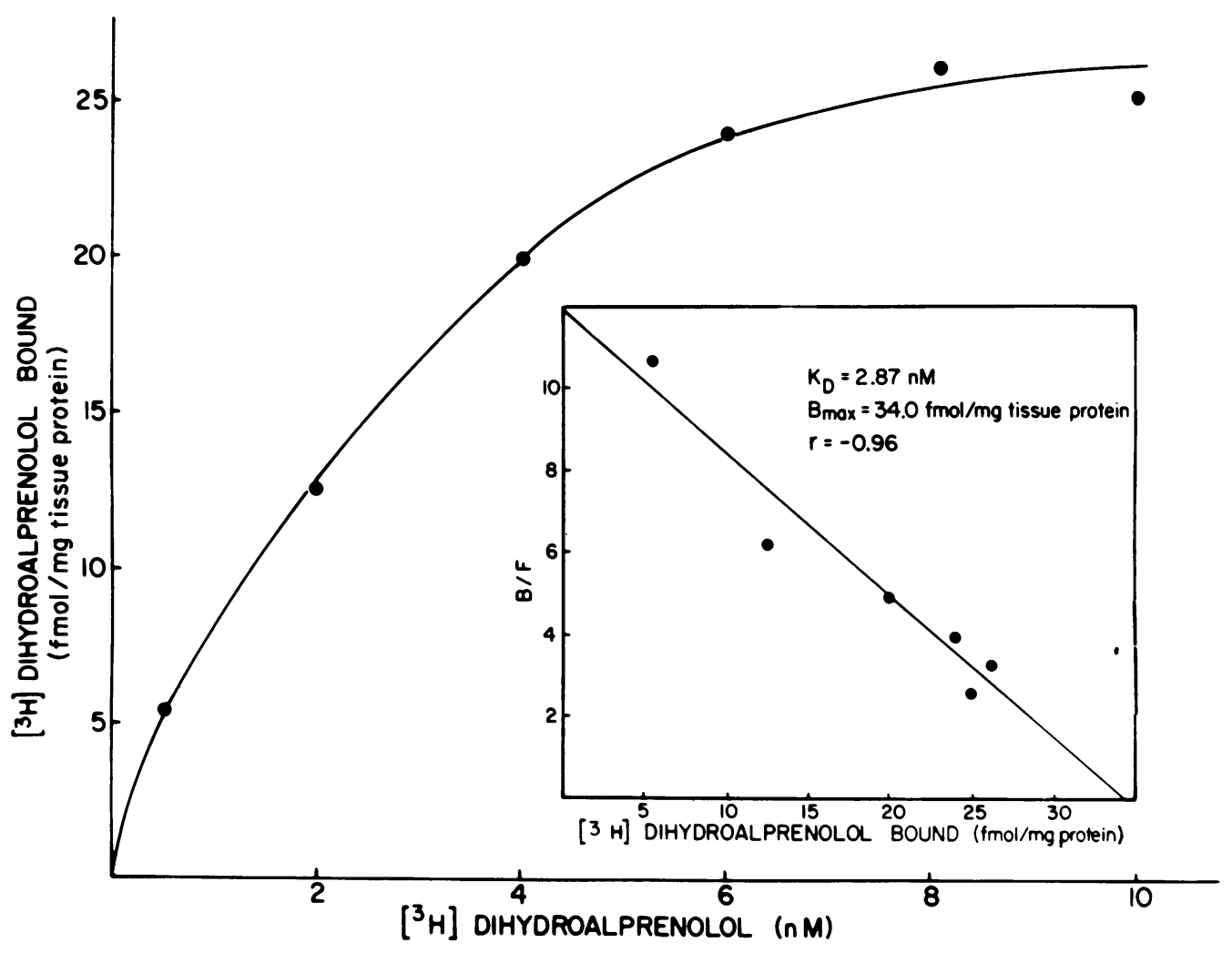

Figure 2. This is a representative curve which plots specific binding of $\left[{ }^{3} \mathrm{H}\right] \mathrm{DHA}$ to tissue sections of dog myocardium as a function of increasing concentration of $\left[{ }^{3} \mathrm{H}\right]$ DHA. Specific binding is defined as $(-)\left[{ }^{3} \mathrm{H}\right] \mathrm{DHA}$ binding displaceable by $10^{-5} \mathrm{M}$ ( \pm )propranolol. Specific binding ranged from $77 \%$ of total binding at $0.5 \mathrm{nM}\left[{ }^{3} \mathrm{H}\right] \mathrm{DHA}$, to $32 \%$ of total binding at 10 $\mathrm{nM}\left[{ }^{3} \mathrm{H}\right] \mathrm{DHA}$, decreasing as the concentration of [ $\left.{ }^{3} \mathrm{H}\right] \mathrm{DHA}$ increased. Inset: Scatchard plot of $\left[{ }^{3} \mathrm{H}\right] \mathrm{DHA}$ binding. The ratio $(B / F)$ of bound $\left[{ }^{3} \mathrm{H}\right] \mathrm{DHA}$ (femtomole per milligram tissue protein) to free $\left[{ }^{3} \mathrm{H}\right]$ DHA (nM) is plotted as a function of the $\left[{ }^{3} \mathrm{H}\right] \mathrm{DHA}$ bound/milligram tissue protein. 


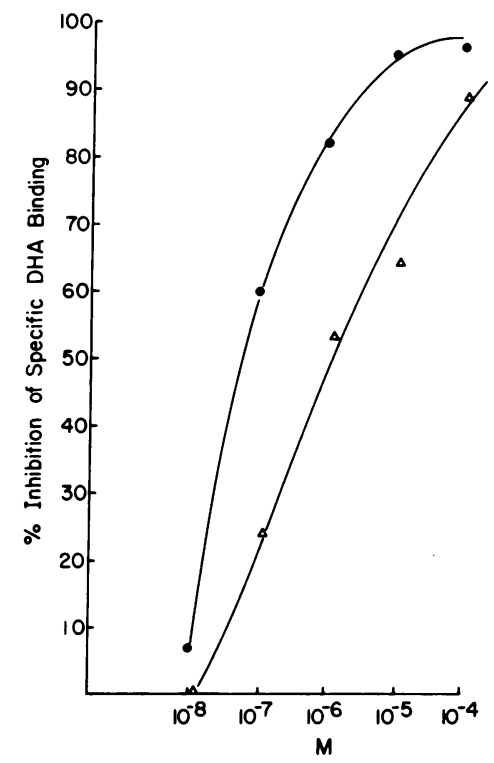

Figure 3. The percent inhibition of specific $\left[{ }^{3} \mathrm{H}\right] \mathrm{DHA}$ binding $(2 \mathrm{nM})$ as a function of increasing concentrations of (-)isoproterenol and (-)norepinephrine. Isoproterenol is 12.5 times more effective at displacing $\left[{ }^{3} \mathrm{H}\right] \mathrm{DHA}$ than norepinephrine. $\bullet$, Isoproterenol $\mathrm{IC}_{50}=8 \times 10^{-8}$; $\Delta$, norepinephrine $\mathrm{IC}_{50}=1$ $\times 10^{-6}$.

heart removed and placed on ice. In one series of experiments, the proximal left anterior descending coronary artery (LAD) and several branch vessels were ligated to create an area of intense cyanosis in the anterior left ventricular wall. After $1 \mathrm{~h}$ of ischemia the heart was removed.

Blocks of left ventricular myocardium, $3 \mathrm{~mm}$ thick, were quickly obtained from the hearts. A block also was taken from the LAD, $2 \mathrm{~cm}$ distal to the ostium of the left coronary artery. Routinely, the blocks were fixed in $0.1 \%$ paraformaldehyde in phosphate-buffered saline for $30 \mathrm{~min}$ at $0-2^{\circ} \mathrm{C}$, and then were snap frozen in a slurry of isopentane cooled in liquid nitrogen. In some experiments, blocks of tissue were frozen without prior fixation. The blocks were stored for one or more days in liquid nitrogen before processing. Tissue sections were cut 10 $\mu \mathrm{m}$ thick in a cryostat microtome and thaw-mounted on acid-washed, subbed slides.

Receptor binding. The slides with tissue sections were incubated at

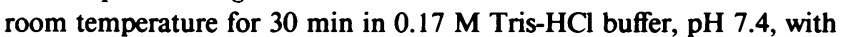
$10 \mathrm{mM} \mathrm{MgCl}$. The sections were incubated with nanomolar concentrations of tritiated (-)DHA, $(-)\left[{ }^{3} \mathrm{H}\right] \mathrm{DHA}(34.1-49.4 \mathrm{Ci} / \mathrm{mM}$, New England Nuclear, Boston, MA), in the presence or absence of various other ligands. In different experiments these ligands were: $10^{-5} \mathrm{M}$ (士)propranolol, $10^{-10}-10^{-5} \mathrm{M}(-)$ propranolol, $10^{-10}-10^{-5} \mathrm{M}(+)$ propranolol, $10^{-5} \mathrm{M}$ phentolamine, $10^{-8}-10^{-4} \mathrm{M}(-)$ isoproterenol, $10^{-8}$ $10^{-5} \mathrm{M}(-)$ norepinephrine, and $10^{-8}-10^{-4} \mathrm{M}$ metoprolol. After incubation with ligands, the slides were washed twice in ice-cold buffer for two 10-min periods, then quickly dipped in distilled water and dried.

In biochemical experiments, the sections were dried, scraped from the slides with a razor blade, placed in scintillation vials, and $5 \mathrm{ml}$ of scintillation fluid added. Four tissue slices were used for each determination. Radioactivity was measured in a liquid scintillation counter. Binding curves and Scatchard plots were generated by standard techniques (5). Tissue protein was measured according to the method of Lowry et al. (11). In displacement experiments, the $\mathrm{IC}_{50}$ was derived from the curve, and the dissociation constant $\left(K_{\mathrm{D}}\right)$ was calculated according to the method of Cheng and Prusoff (12).

Autoradiography. Acid-washed coverslips were coated by dipping into NTB 2 emulsion (Eastman Kodak Co., Rochester, NY) (diluted
1:1 with water) at $43^{\circ} \mathrm{C}$, air dried for $3 \mathrm{~h}$, and stored over desiccant. The emulsion-coated coverslips were attached to the slides with tissue sections in the dark with glue (Super Glue No. 3., Loctite Corp., Cleveland, $\mathrm{OH}$ ), which was placed on one end of the slide. After the glue set, squares of Teflon ( $1 / 8$ in. thick) were put on top of the coverslips and the assemblies were held together with No. 20 binder clips. The assemblies were stored with desiccant at $2-4^{\circ} \mathrm{C}$.

After several weeks exposure, the autoradiographs were developed. The binder clips and Teflon were removed in the dark, the coverslips were gently bent away from the tissue sections, and a rubber spacer was placed between the slide and coverslip. The emulsion was developed in D19 (1:1 with water) for $4 \mathrm{~min}$ at $18^{\circ} \mathrm{C}$, rinsed with deionized water for $15 \mathrm{~s}$, fixed in Kodak fixer (Eastman Kodak Co.) for $5 \mathrm{~min}$, and rinsed in distilled water for 20 min. The tissues were fixed in Carnoy's solution and stained with Meyer's hematoxylin and eosin. The spacers were removed after the tissues had dried and the coverslips were mounted with Permount (Fisher Scientific Co., Pittsburgh, PA).

Autoradiographic grain distribution was analyzed with a Zeiss microscope (Carl Zeiss, Inc., New York) at a magnification of 1,250 using a square grid subdivided into $\mathbf{4 0 0}$ smaller squares. Five large grid areas were analyzed over the subendocardial myocytes, the subepicardial myocytes, and the media of the proximal LAD. The number of squares of the grid into which the wall of a small artery ( $>55 \mu \mathrm{m} \mathrm{o.d.)}$ or an arteriole ( $<55 \mu \mathrm{m}$ o.d.) fit was recorded, and the grains in that area were counted. All arterioles with a definite smooth muscle layer and all small arteries in a tissue section were counted. This was an average of nine arterioles, and three small arteries per tissue section. Nonspecific grain density over serial sections from the same block incubated in $(-)\left[{ }^{3} \mathrm{H}\right] \mathrm{DHA}$ plus $10^{-5} \mathrm{M}( \pm)$ propranolol was subtracted from total grain density over sections incubated in $(-)\left[{ }^{3} \mathrm{H}\right] \mathrm{DHA}$ to determine the grain density specific for binding to beta adrenergic receptors.

Statistics. The $t$ test, analysis of variance, and the Kruskall-Wallis test were used as appropriate (13).

\section{Results}

Biochemical characteristics of receptor binding. The slide incubation, tissue scraping, and scintillation counting procedures were used to obtain biochemical data regarding receptor binding with the technique used for autoradiography. Binding of $(-)\left[{ }^{3} \mathrm{H}\right] \mathrm{DHA}$ to the tissue sections reached equilibrium after 15 min of incubation at room temperature (Fig. 1). The binding was not affected by brief fixation of tissue in $0.1 \%$ paraformaldehyde. Binding curves indicated a saturable binding process (Fig. 2). Data were obtained by incubating sections in 0.5-10 $\mathrm{nM}(-)\left[{ }^{3} \mathrm{H}\right] \mathrm{DHA}$ in the presence or absence of $10^{-5} \mathrm{M}( \pm)$ propranolol. With Scatchard analysis, the $K_{\mathrm{D}}$ for $(-)\left[{ }^{3} \mathrm{H}\right] \mathrm{DHA}$ binding was $3.2 \pm 0.5 \mathrm{nM}$ (SD) $(n=3$ experiments), and the maximal binding (B max) was $31.3 \pm 3.1 \mathrm{fmol} / \mathrm{mg}$ tissue protein (Fig. 2, inset). Specific binding ranged from $77 \%$ of total binding at $0.5 \mathrm{nM}\left[{ }^{3} \mathrm{H}\right] \mathrm{DHA}$ to $32 \%$ of total binding at $10 \mathrm{nM}\left[{ }^{3} \mathrm{H}\right] \mathrm{DHA}$. Specific binding decreased as the concentration of $\left[{ }^{3} \mathrm{H}\right] \mathrm{DHA}$ increased. For most experiments, a concentration of $2 \mathrm{nM}$ $\left[{ }^{3} \mathrm{H}\right] \mathrm{DHA}$ was chosen, since it provided a relatively high concentration and relatively high specific binding $(\sim 70 \%)$.

Slide-mounted tissue sections were incubated with varying concentrations $\left(10^{-4}-10^{-10} \mathrm{M}\right)$ of $(+)$ and $(-)$ propranolol in the 

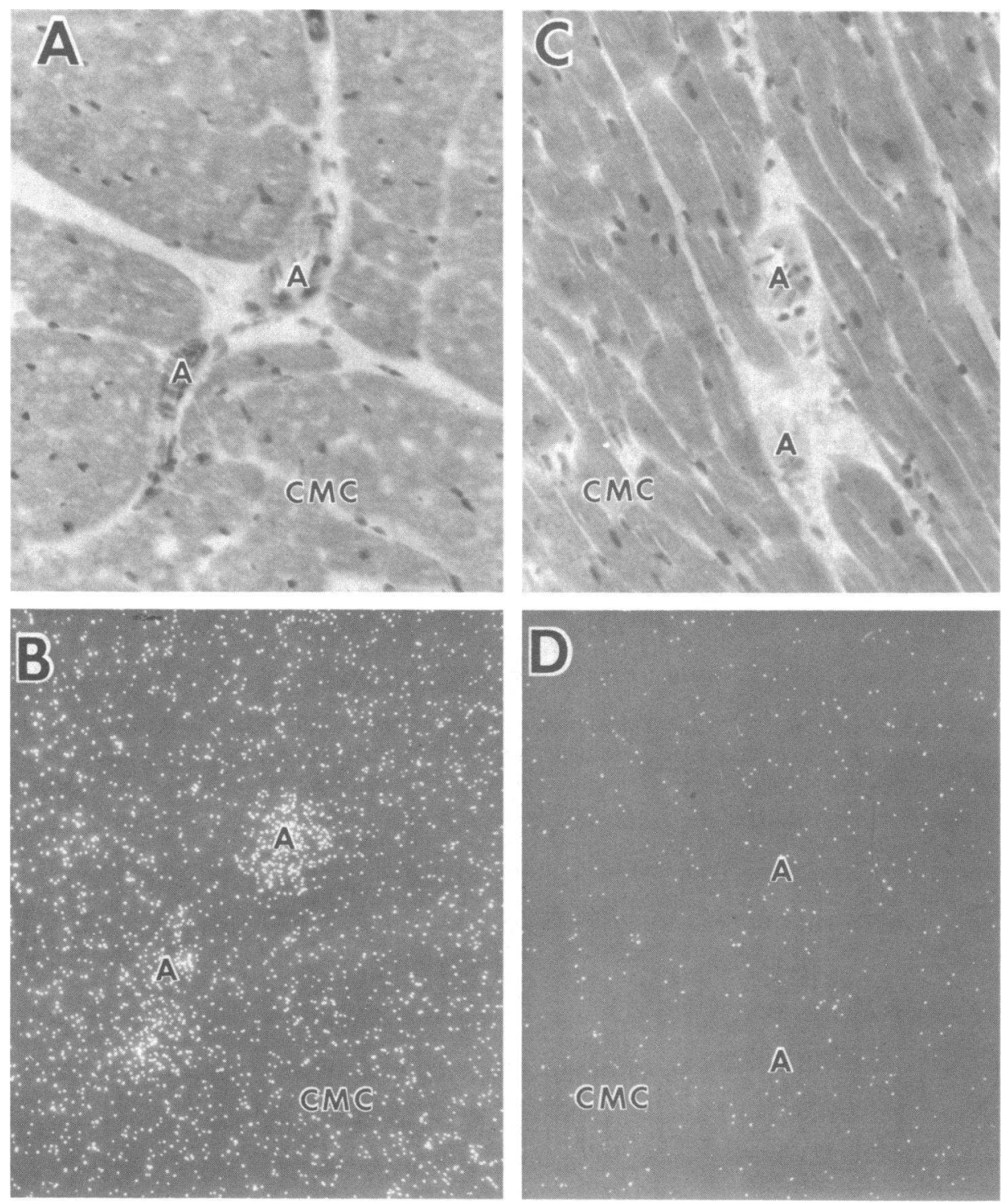

Figure 4. Photomicrographs of [ $\left.{ }^{3} \mathrm{H}\right] \mathrm{DHA}$ autoradiographs taken at $200 \times$ magnification. Pictures on the top are taken with a bright-field condensor and pictures on the bottom are the same fields taken with a darkfield condensor. ( $A$ and $B$ ) $\mathrm{A}$ tissue section incubated with $2 \mathrm{nM}$ $\left[{ }^{3} \mathrm{H}\right]$ DHA (i.e., total binding). Note the increased grains over the arterioles $(A)$ when compared with cardiac muscle cells (CMC). ( $C$ and $D$ ) A serial section incubated with $\left[{ }^{3} \mathrm{H}\right] \mathrm{DHA}$ in the presence of $10^{-5} \mathrm{M}( \pm)$ propranolol (i.e., nonspecific binding). Note the reduction in grain density and the equal distribution of grains over myocytes and arterioles. presence of $2 \mathrm{nM}(-)\left[^{3} \mathrm{H}\right] \mathrm{DHA}$. The (-)propranolol was over 100 times more effective $\left(\mathrm{IC}_{50}=9 \times 10^{-10}\right)$ than the $(+)$ propranolol $\left(\mathrm{IC}_{50}=1 \times 10^{-7} \mathrm{M}\right)$ in displacing $(-)\left[{ }^{3} \mathrm{H}\right] \mathrm{DHA}$, indicating that the method for labeling beta-adrenergic receptors shows stereospecificity. In another experiment, no displacement of $2 \mathrm{nM}(-)$ DHA was measured in the presence of $10^{-5} \mathrm{M}$ phentolamine, an alpha adrenergic antagonist.

Tissue sections were incubated with varying concentrations $\left(10^{-4}-10^{-8} \mathrm{M}\right)$ of $(-)$ isoproterenol and $(-)$ norepinephrine in the presence of $2 \mathrm{nM}(-)\left[{ }^{3} \mathrm{H}\right] \mathrm{DHA}$ (Fig. 3). Isoproterenol was 12.5 times more effective at displacing $(-)\left[{ }^{3} \mathrm{H}\right] \mathrm{DHA}\left(\mathrm{IC}_{50}=8\right.$ $\left.\times 10^{-8}\right)$ than norepinephrine $\left(\mathrm{IC}_{50}=1 \times 10^{-6}\right)$, in accordance with binding characteristics of the beta adrenergic receptor (4).

Sections also were incubated with $10^{-5}-10^{-8} \mathrm{M}$ metoprolol, a beta one selective antagonist, in the presence of $2 \mathrm{nM}$ $(-)\left[{ }^{3} \mathrm{H}\right] \mathrm{DHA}$. Metoprolol exhibited a $K_{\mathrm{D}}$ of $0.7 \times 10^{-6} \mathrm{M}$.

Autoradiographic localization of $(-)\left[{ }^{3} \mathrm{H}\right] \mathrm{DHA}$ binding sites. Autoradiographic grains appeared to be distributed uniformly over cardiac myocytes in normal canine myocardium (Figs. 4 and 5). Arterioles were heavily labeled when compared with the myocytes. Serial sections incubated with $\left[{ }^{3} \mathrm{H}\right] \mathrm{DHA}$ in the presence of propranolol had fewer grains, and grains were equally distributed over myocytes and arterioles (Fig. 4). Tritiated DHA binding could not be localized to the sarcolemma or any other subcellular organelle. However, there were obvious demarcations between grain density over myocytes, connective tissue, and areas of the slides without tissue (background). Specific binding was similar over cardiac myocytes in the subepicardial $(208 \pm 29$ 

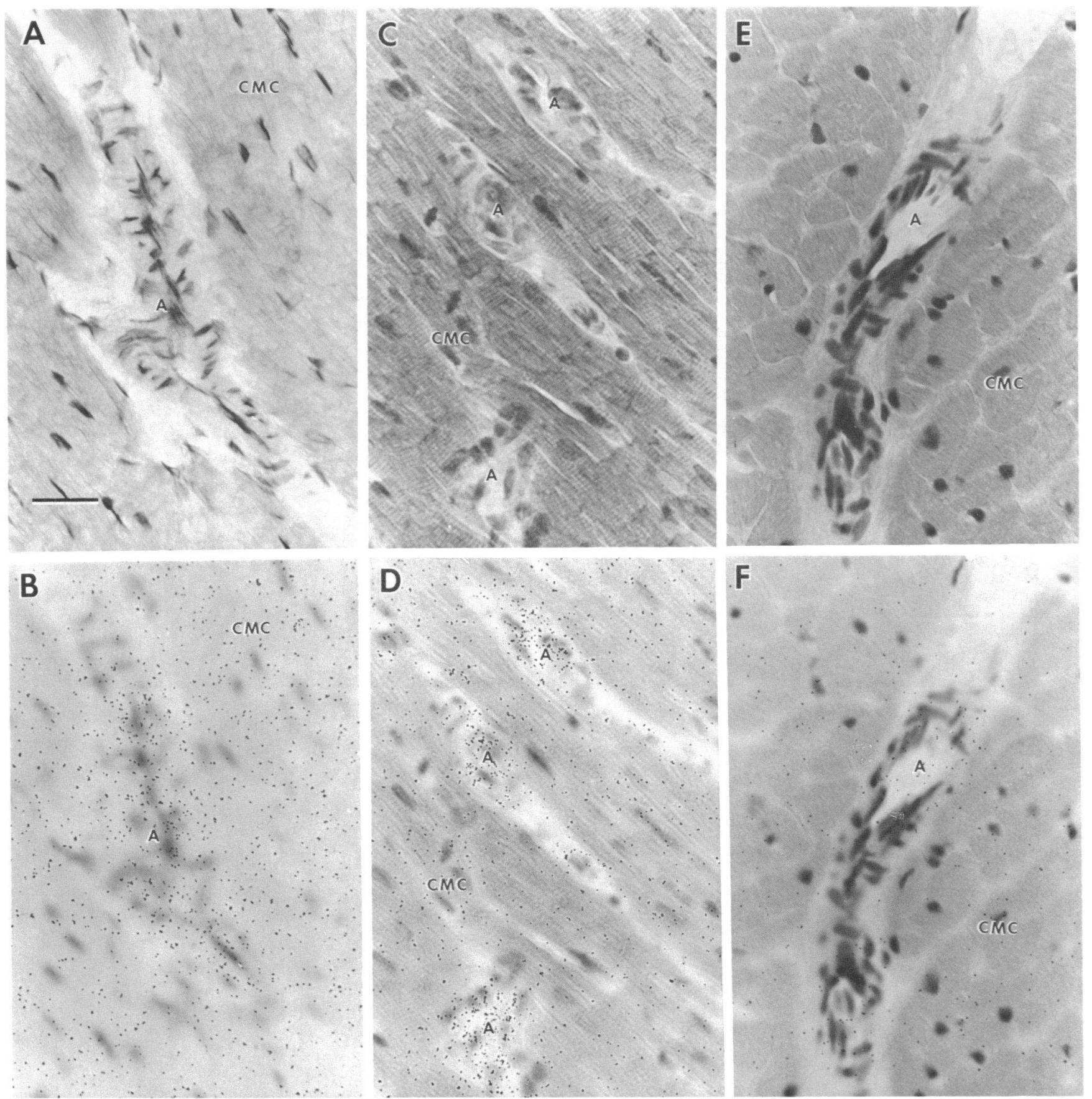

Figure 5. Photomicrographs of $\left[{ }^{3} \mathrm{H}\right] \mathrm{DHA}$ autoradiographs taken at $750 \times$ magnification. Pictures on the top row were taken with tissue in focus and pictures on the bottom row were the same field taken with grains in focus. $(A$ and $B) A$ tissue section incubated with $2 \mathrm{nM}$ $\left[{ }^{3} \mathrm{H}\right] \mathrm{DHA}$ (i.e., total binding). Note that grain density indicative of beta adrenergic receptor binding is moderate over the $\mathrm{CMC}$ and more intense over the myocardial arteriole $(A)$. $(C$ and $D) \mathrm{A}$ tissue section incubated with $2 \mathrm{nM}\left[{ }^{3} \mathrm{H}\right] \mathrm{DHA}$ in the presence of $10^{-6} \mathrm{M}$ metoprolol, a beta one selective antagonist. Note that binding is decreased over the CMC but is not decreased over myocardial arterioles $(A)$. $(E$ and $F)$. A tissue section incubated with $2 \mathrm{nM}\left[{ }^{3} \mathrm{H}\right] \mathrm{DHA}$ in the presence of $10^{-5}$ metoprolol. Note that binding is decreased over both the CMC and the myocardial arterioles $(A)$. Scale bar, $20 \mu \mathrm{m}$. 

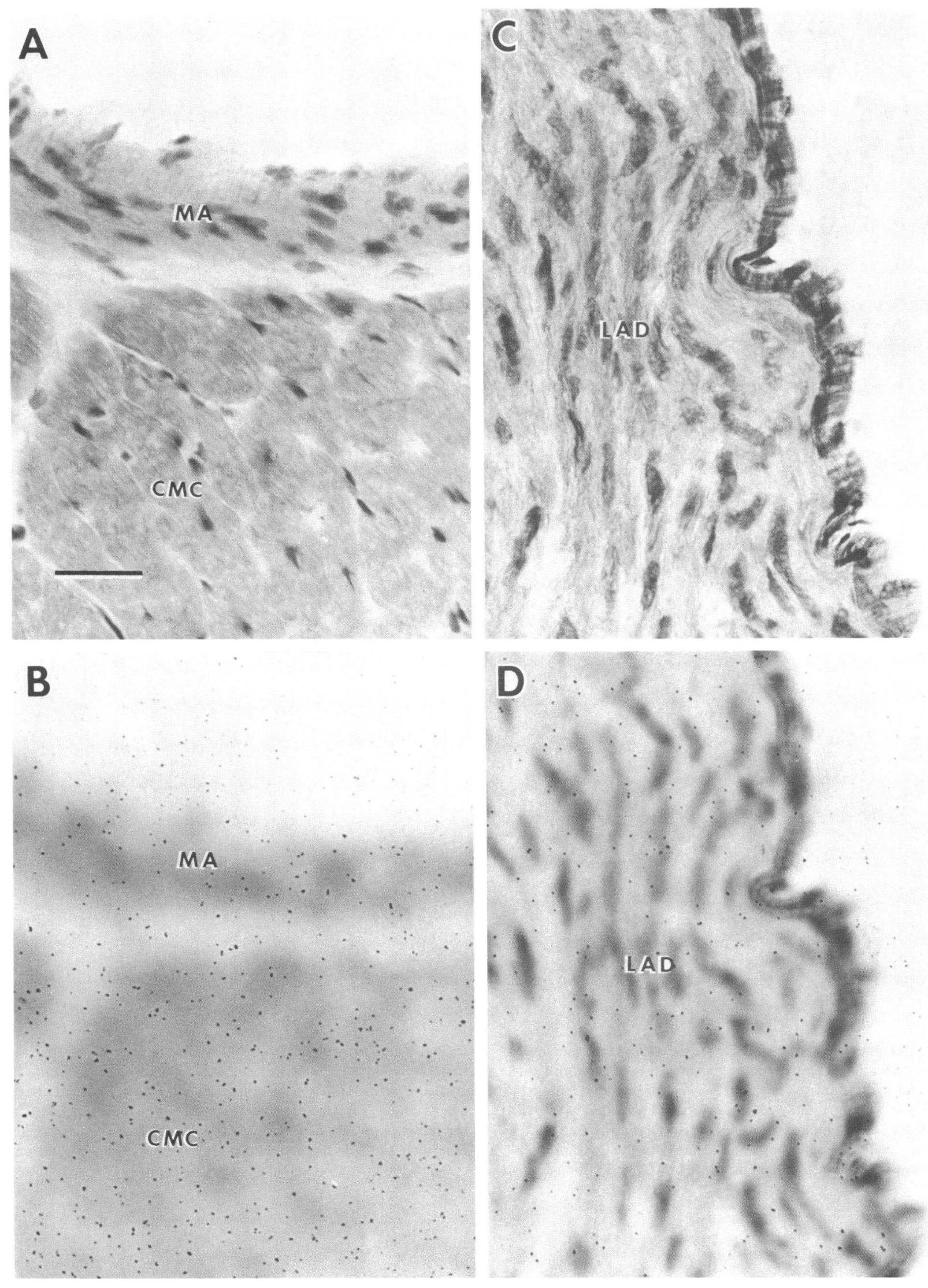
Table I. Autoradiographic Distribution of Specific $(-)\left[{ }^{3} \mathrm{H}\right] \mathrm{DHA}$ Binding Sites in the Normal Canine Heart ( $n=4$ dogs)

\begin{tabular}{lc}
\hline Site & Grains $/ 10^{-2} \mathrm{~mm}^{2}$ \\
\hline CMC & $231 \pm 34(\mathrm{SEM})^{\mathrm{a}}$ \\
Myocardial arterioles $(<55 \mu \mathrm{m}$ o.d.) & $1,047 \pm 131^{\mathrm{b}}$ \\
MA & $219 \pm 30^{\mathrm{a}}$ \\
Proximal LAD & $31 \pm 12^{\mathrm{c}}$ \\
\hline
\end{tabular}

$\mathrm{a} \neq \mathrm{b} \neq \mathrm{c}$ with the Kruskall-Wallis test $(P<0.001)$.

(SEM) grains $/ 10^{-2} \mathrm{~mm}^{2}$ ) and subendocardial (182 \pm 25$)$ regions of the anterior left ventricle and the subepicardial $(212 \pm 12)$ and subendocardial $(196 \pm 26)$ regions of the posterior left ventricle ( $n=3$ dogs). The average specific binding over cardiac myocytes was $67 \%$ of total binding. The grain density over the walls of small to medium-sized arteries was slightly less than over surrounding cardiac myocytes (Table I) (Fig. 6, $A$ and $B$ ). The grain density over the wall of the proximal LAD was low (Table I) (Fig. 6, $C$ and $D$ ).

Many arterioles had a much greater specific grain density than both surrounding cardiac myocytes and myocardial arteries (Table I). We analyzed vessels with a definite smooth muscle layer and with outer diameter of $<55 \mu \mathrm{m}$. Specific binding over arterioles was five times greater than over surrounding cardiac myocytes and arteries. Nevertheless, after determining the percent area of myocardium occupied by arterioles, it was calculated that specific binding by arterioles represented $1.38 \pm 1.29 \%$ (SD) of total myocardial specific binding activity. The grain density over arterioles was less homogeneous than over arteries, with areas of increased binding within segments of the same vessel. There was also greater variability among the counts over arterioles than the counts over the cardiac myocytes in the same tissue. The grain density over veins, venules, and capillaries was low.

Autoradiographic characterization of metoprolol effects. The effects of the beta one selective adrenergic antagonist, metoprolol, on $\left[{ }^{3} \mathrm{H}\right]$ DHA binding was dose dependent (Table II, Fig. 5). Metoprolol at $10^{-5} \mathrm{M}$ resulted in a $75 \%$ reduction in $\left[{ }^{3} \mathrm{H}\right] \mathrm{DHA}$ binding over all structures studied, i.e., cardiac myocytes and arterioles (Table II, Fig. 5). However, the absolute numbers of grains over arterioles was five times higher than over cardiac myocytes. The proximal LAD was not studied because specific DHA binding was very low. At $10^{-6} \mathrm{M}$ metoprolol, $\left[{ }^{3} \mathrm{H}\right] \mathrm{DHA}$ binding to cardiac myocytes was reduced by $50 \%$, whereas binding to arterioles was not significantly reduced (Table II, Fig. 5). At $10^{-7} \mathrm{M}$ metoprolol, $17 \%$ inhibition of $\left[{ }^{3} \mathrm{H}\right] \mathrm{DHA}$ binding occurred over cardiac myocytes, but there was no inhibition over arterioles (Table II).

In the biochemical studies with metoprolol, specific [ ${ }^{3} \mathrm{H}$ ]DHA binding to myocardial sections was reduced by $82 \%$ with $10^{-5} \mathrm{M}$ metoprolol, $49 \%$ in the presence of $10^{-6} \mathrm{M}$ metoprolol, and $17 \%$ in the presence of $10^{-7} \mathrm{M}$ metoprolol. Thus, the percent displacement in the biochemical studies was similar to the displacement of $\left[{ }^{3} \mathrm{H}\right] \mathrm{DHA}$ by metoprolol found over cardiac myocytes in the autoradiographic binding studies (Table II).

Autoradiography of ischemic vs. control myocardium. Specific binding of $(-)\left[{ }^{3} \mathrm{H}\right]$ DHA was increased significantly (average of $\sim 18 \%$ ) over cardiac myocytes from anterior myocardium subjected to $1 \mathrm{~h}$ of ischemia (Table III). The same result was obtained when the data were analyzed with a repeated-measures analysis of variance $(P<0.003)$. There was no significant difference between binding over cardiac myocytes in the subendocardial and subepicardial regions of the ischemic area. We were unable to demonstrate any significant differences between arterioles from ischemic and nonischemic myocardium. However, the number of blood vessels available for analysis was relatively small, and there was greater variability of binding over blood vessels.

\section{Discussion}

The system of in vitro labeling of tissue sections, developed by Young and Kuhar (7) and Palacios and Kuhar (8) for brain tissue, offers several advantages for studying receptors in heart and other organs. Specifically, this technique allows quantification of nonspecific binding and total binding in serial tissue sections; it offers the potential of simultaneously studying several receptor systems in the same tissue, and it is not dependent on vascular delivery or diffusion of ligand. The latter point is particularly important in analyzing relative differences in binding to different tissue components, such as blood vessels and cardiac myocytes. In addition, the technique allows pharmacological verification of the receptor system being studied. We performed biochemical studies to characterize the properties of receptor binding with the technique used for autoradiography. The results of these experiments indicated that the method demonstrates authentic beta adrenergic receptor activity. With the autoradiographic method, we could easily separate the grain density over cardiac myocytes, blood vessels, connective tissue, and background. However, the resolution of this system was not adequate to localize $(-)\left[{ }^{3} \mathrm{H}\right]$ DHA binding to compartments of individual cells.

A most striking result of our study was the distribution of beta adrenergic receptors over blood vessels. We found a fivefold
Figure 6. Photomicrographs of $\left[{ }^{3} \mathrm{H}\right] \mathrm{DHA}$ autoradiographs taken at $750 \times$ magnification with tissue in focus (top row) and with grains in focus (bottom row). ( $A$ and $B$ ) Myocardial artery (MA). ( $C$ and $D$ ) Proximal LAD. The photomicrographs show silver grains over sec- tions incubated with 2 nM DHA (i.e., total binding). Note that binding over the MA is slightly less than the adjacent CMC and that binding is very low over the LAD. Scale bar $=20 \mu \mathrm{m}$. 
Table II. Specific (-) [ $\left.{ }^{3} H\right] D H A$ Binding in the Presence and Absence of Metoprolol

\begin{tabular}{|c|c|c|c|c|}
\hline \multirow[b]{2}{*}{ Incubation conditions } & \multicolumn{2}{|c|}{ CMC } & \multicolumn{2}{|c|}{ Myocardial arterioles } \\
\hline & Grains $/ 10^{-2} \mathrm{~mm}^{2}$ & $\%$ Inhibition & Grains $/ 10^{-2} \mathrm{~mm}^{2}$ & \% Inhibition \\
\hline 2 nM DHA $(n=3$ dogs $)$ & $200 \pm 23(\mathrm{SEM})$ & & $1,000 \pm 174$ & \\
\hline $2 \mathrm{nM}$ DHA $+10^{-5} \mathrm{M}$ metoprolol & $46 \pm 8$ & $76.8 \pm 3.4^{\mathrm{a}}$ & $250 \pm 92$ & $70.1 \pm 14.0^{\mathrm{a}}$ \\
\hline 2 nM DHA ( $n=3$ dogs) & $338 \pm 24$ & & $1,165 \pm 155$ & \\
\hline $2 \mathrm{nM}$ DHA $+10^{-6} \mathrm{M}$ metoprolol & $168 \pm 8$ & $50.0 \pm 1.2^{\mathrm{b}}$ & $1,225 \pm 168$ & $-4.5 \pm 3.9^{b}$ \\
\hline $2 \mathrm{nM}$ DHA $(n=3$ dogs $)$ & $338 \pm 24$ & & $1,165 \pm 155$ & \\
\hline $2 \mathrm{nM} \mathrm{DHA}+10^{-7} \mathrm{M}$ metoprolol & $275 \pm 12$ & $17.4 \pm 8.5^{\mathrm{c}}$ & $1,201 \pm 141$ & $-2.8 \pm 7.4^{b \prime}$ \\
\hline
\end{tabular}

$\mathrm{a} \neq \mathrm{b} \neq \mathrm{c}$ and $\mathrm{a} \neq \mathrm{b}^{\prime}$ with one-way analysis of variance $(P<0.001)$.

greater density of autoradiographic grains over arterioles as compared with small and medium-sized arteries and a 34-fold greater density compared with the proximal LAD. These results may be related to the high concentration of adrenergic nerve terminals associated with coronary arterioles (14). They are also consistent with physiologic studies demonstrating variation in the response pattern to various adrenergic interventions according to the size of the coronary vessel (15). These results may have important implications regarding the regional control of coronary blood flow by the adrenergic nervous system. Although the specific binding over arterioles was very high, its contribution to total myocardial binding was small, averaging only $1.4 \%$.

Pharmacological studies done in rat demonstrate both beta one and beta two receptors in the heart (2), with a predominance of beta one receptors (85\%). Both beta one and beta two receptors have been identified in cerebral microvessels. However, the majority of beta receptors in this preparation were of the beta two type $(85 \%)$ (16). In our studies, we found that $10^{-6}$ and $10^{-7}$ M metoprolol displaced $\left[{ }^{3} \mathrm{H}\right] \mathrm{DHA}$ over cardiac myocytes but not over arterioles, suggesting that the cardiac myocytes are a major site of localization of beta one receptors in the canine heart. The dose-related binding over the cardiac myocytes was

Table III. Autoradiographic Distribution of Specific (-) [ $\left.{ }^{3} H\right] D H A$ Binding Sites in Control vs. Ischemic Myocardium after $1 \mathrm{H}$ of Occlusion of the Proximal LAD

\begin{tabular}{llll}
\hline & $\begin{array}{l}\text { Cardiac } \\
\text { myocyctes } \\
\text { subepicardium } \\
(n=6)\end{array}$ & $\begin{array}{l}\text { Cardiac } \\
\text { myocytes } \\
\text { subendocardium } \\
(n=6)\end{array}$ & $\begin{array}{l}\text { Arterioles } \\
(n=5)\end{array}$ \\
\hline Tissue & $234 \pm 31$ & $240 \pm 31$ & $1,173 \pm 147$ \\
\hline $\begin{array}{c}\text { Control } \\
\text { myocardium* }\end{array}$ & $275 \pm 29 \ddagger$ & $283 \pm 33 \ddagger$ & $1,335 \pm 138$ \\
$\begin{array}{c}\text { Ischemic } \\
\text { myocardium* }\end{array}$ & 29 & \\
\hline
\end{tabular}

* Data are expressed as grains $/ 10^{-2} \mathrm{~mm}^{2}(\overline{\mathrm{x}} \pm \mathrm{SEM})$.

$\ddagger P<0.01$; ischemic vs. control myocardium, paired $t$ test. similar to myocardial binding of metoprolol determined by scintillation spectrometry; however, the binding to arterioles was not. This probably reflects the low contribution of arterioles to the beta receptor population in the heart. Definitive data on the numbers of beta one and beta two receptors over different tissue compartments could only be obtained with additional autoradiographic studies using varying concentrations of several beta one and beta two selective antagonists. It is also interesting to note that the selective response of cardiac muscle cells and blood vessels to metoprolol is dose dependent. This finding is in agreement with clinical findings in which the beta one selectivity of metoprolol is lost when plasma levels of the drug are high (17).

Using membrane binding assays with $(-)\left[{ }^{3} \mathrm{H}\right] \mathrm{DHA}, \mathrm{Mu}-$ kherjee et al. (18-20) have previously reported no regional differences in beta adrenergic receptor number in the left ventricle of sham-operated dogs. However, in myocardium subjected to $1 \mathrm{~h}$ of ischemia, there was a significant increase in beta adrenergic receptor numbers, although binding affinity was not different between ischemic and nonischemic areas. The topographical distribution of the increased population of receptors was not determined. Our autoradiographic data extend the previous findings by demonstrating that ischemia produces a change in the number of beta adrenergic receptors predominantly in cardiac muscle cells rather than in other structures of the heart. The increase in beta adrenergic receptor number in ischemic myocardium was greater in the previous studies (18-20), which used membrane homogenates $(60 \%$ increase) than in the present autoradiographic study ( $18 \%$ increase). This difference could be due to interanimal variation in the degree of ischemia or to detection of different subgroups of the total population of beta adrenergic receptors by the two methods. In addition to the receptors on the cell membrane, the autoradiographic method could have visualized receptors in the cytosol, which were physiologically inactive $(21,22)$. The mechanism responsible for the increased beta adrenergic receptor number in ischemic cardiac myocytes is unclear. The phenomenon may be related to unmasking of sarcolemmal receptors, possibly due to changes in membrane fluidity (23), or to inhibition of membrane receptor internalization, and ATP-dependent process (21). 
In conclusion, using an autoradiographic technique developed by Young and Kuhar (7) and Palacios and Kuhar (8), we have determined the distribution of beta adrenergic receptor binding over canine cardiac myocytes and myocardial blood vessels. We also have characterized the response of the beta adrenergic receptors of these structures to the selective beta one adrenergic receptor antagonist, metoprolol. In addition, we have verified an increase of specific $(-)\left[{ }^{3} \mathrm{H}\right] \mathrm{DHA}$ binding over cardiac myocytes in both subendocardial and subepicardial regions of ischemic myocardium. Data obtained in this study have demonstrated directly the distribution of beta adrenergic receptors in striated myocytes and blood vessels of the canine heart, and have shown that changes in beta adrenergic receptor density occur selectively in certain components of the heart in response to pharmacological and pathological perturbations.

\section{Acknowledgments}

We would like to thank Dorothy Thomas and Judy Ober for expert technical assistance and Deborah Granville for excellent secretarial help in preparation of the manuscript.

This work was supported by National Institutes of Health (NIH) Ischemic Heart Disease SCOR grant P50-HL-17669, a grant from the Harry S. Moss Heart Fund, and NIH National Research Service Awards F32-HL-06591, T32-HL-07360, and T35-HL-07483, and a grant from the American Heart Association.

\section{References}

1. Lands, A. M., A. Arnold, J. P. McAuliff, F. P. Ludvena, and T. C. Brown. 1967. Differentiation of receptor systems activated by sympathomimetic amines. Nature (Lond.). 214:597-598.

2. Minneman, K. P., L. R. Hegstrand, and P. B. Molinoff. 1979. Simultaneous determination of beta- 1 and beta- 2 adrenergic receptors in tissues containing both receptor subtypes. Mol. Pharmacol. 16:3446.

3. Williams, R. S., D. F. Dukes, and R. J. Lefkowitz. 1981. Subtype specificity of alpha-adrenergic receptors in rat heart. J. Cardiovasc. Pharmacol. 3:522-531.

4. Alquist, R. P. 1948. Study of adrenotropic receptors. Am. J. Physiol. 153:586-600.

5. Williams, L. T., and R. J. Lefkowitz. 1978. Receptor Binding Studies in Adrenergic Pharmacology. Raven Press, New York. 27-42.

6. Watanabe, A. M., L. R. Jones, A. S. Manalan, and H. R. Besch. 1982. Cardiac autonomic receptors. Recent concepts from radiolabeled ligand-binding studies. Circ. Res. 50:161-174.

7. Young, W. S., and M. J. Kuhar. 1979. A new method for receptor autoradiography: ${ }^{3} \mathrm{H}$-opioid receptor labeling in mounted tissue sections. Brain Res. 179:255-270.
8. Palacios, J. M., and M. J. Kuhar. 1980. Beta-adrenergic receptor localization by light microscopic autoradiography. Science (Wash. DC). 208:1378-1380.

9. Lavenstein, B., W. K. Engel, N. B. Peddy, and S. Carroll. 1979. Autoradiographic visualization of beta-adrenergic receptors in normal and denervated skeletal muscle. J. Histochem. Cytochem. 27:1308-1311.

10. Azevedo, I., H. Bonisch, W. Osswald, and V. Trendelenburg. 1983. Autoradiographic study of rat hearts perfused with ${ }^{3} \mathrm{H}$-Isoprenaline. Naunyn-Schmiedeberg's Arch Pharmacol. 322:1-5.

11. Lowry, O. H., N. J. Rosenbrough, A. L. Farr, and R. J. Randall. 1951. Protein measurement with the Folin-phenol reagent. J. Biol. Chem. 193:265-275.

12. Cheng, Y., and W. H. Prusoff. 1973. Relationship between the inhibition constant $\left(\mathrm{K}_{\mathrm{I}}\right)$ and the concentration of inhibitor which causes $50 \%$ inhibition $\left(I_{50}\right)$ of an enzymatic reaction. Biochem. Pharmacol. 22:3099-3108.

13. Zar, J. H. 1974. Biostatistical Analysis. Prentice-Hall Inc., Englewood Cliffs, NJ. 121-124, 139-142.

14. Pace, J. B. 1977. Autonomic control of the coronary circulation. In Neural Regulation of the Heart. W. C. Randall, editor. Oxford University Press, New York. 315-344.

15. Morishita, H. 1979. Distribution and characterization of the adrenoceptors in dog coronary artery. Arch. Int. Pharmacodyn. 239:195207.

16. Kobayashi, H., T. Maoret, M. Ferrante, P. Spano, and M. Trabucchi. 1981. Subtypes of beta-adrenergic receptors in rat cerebral microvessels. Brain Res. 220:194-198.

17. Formgren, H. 1981. The effect of metoprolol and practolol on lung function and blood pressure in hypertensive asthmatics. Br. J. Clin. Pharmacol. 3:1007-1014.

18. Mukherjee, A., T. M. Wong, L. M. Buja, R. J. Lefkowitz, and J. T. Willerson. 1979. Beta adrenergic and muscarinic cholinergic receptors in canine myocardium. Effects of ischemia. J. Clin. Invest. 64:1423-1428.

19. Mukherjee, A., K. McCoy, R. Lefkowitz, L. M. Buja, and J. T. Willerson. 1979. Evaluation of mechanisms involved in increasing beta adrenergic receptor numbers in left ventricular ischemic tissue during experimental myocardial ischemia. Circ. Suppl. 60(Suppl. II):II-273.

20. Mukherjee, A., L. R. Bush, K. E. McCoy, R. J. Duke, H. Hagler, L. M. Buja, and J. T. Willerson. 1982. Relationship between $\beta$-adrenergic receptor number and physiological responses during experimental canine myocardial ischemia. Circ. Res. 50:735-741.

21. Chuang, D. M., and E. Costa. 1979. Evidence for internalization of the recognition site of beta-adrenergic receptors during receptor subsensitivity induced by (-)isoproterenol. Proc. Natl. Acad. Sci. USA. 76:3024-3028.

22. Chuang, D. M., W. J. Kinnier, L. Farber, and E. Costa. 1980. A biochemical study of receptor internalization during $\beta$-adrenergic receptor desensitization in frog erythrocytes. Mol. Pharmacol. 18:348355.

23. Strittamatter, W. J., F. Hirata, and J. Axelrod. 1979. Phospholipid methylation unmasks cryptic beta-adrenergic receptors in rat reticulocytes. Science (Wash. DC). 204:1205-1207. 